\title{
Effects of different surface treatments and accelerated artificial aging on the bond strength of composite resin repairs
}

\begin{abstract}
Marco Aurélio Veiga de Melo(a)
Marcos Ribeiro Moysés ${ }^{(a)}$

Saulo Galvão dos Santos ${ }^{(a)}$

Carlos Eduardo Pinto Alcântara ${ }^{(b)}$

José Carlos Rabelo Ribeiro(a)
\end{abstract}

(a) Department of Restorative Dentistry, Três Corações Dental School, Vale do Rio Verde University, UNINCOR, Três Corações, MG, Brazil.

(b) Department of Dentistry, Federal University of Vales do Jequitinhonha e Mucuri, UFVJM, Diamantina, MG, Brazil.

Declaration of Interests: The authors certify that they have no commercial or associative interest that represents a conflict of interest in connection with the manuscript.

Corresponding author:

Marcos Ribeiro Moysés

E-mail: marcos.ribeiro.moise@terra.com.br

Received for publication on Jul 12, 2011 Accepted for publication on Oct 05, 2011
Abstract: The purpose of the present study was to assess the bond strength of composite resin repairs subjected to different surface treatments and accelerated artificial aging. 192 cylindrical samples (CSs) were prepared and divided into 24 groups $(\mathrm{n}=8)$. Half of the CSs were stored in water for $24 \mathrm{~h}$, and the other half were subjected to C-UV accelerated aging for non-metallic specimens. The treatments were phosphoric acid + silane + adhesive (PSA); phosphoric acid + adhesive (PA); diamond bur + phosphoric acid + silane + adhesive (DPSA); diamond bur + phosphoric acid + adhesive (DPA); air abrasion + phosphoric acid + silane + adhesive (APSA); and air abrasion + phosphoric acid + adhesive (APA). The repair was performed and the specimens were again aged as described above. A control group ( $\mathrm{n}=8$ ) was established and did not receive any type of aging or surface treatment. The specimens were loaded to failure in shear mode with a crosshead speed of $0.5 \mathrm{~mm} / \mathrm{min}$ until fracture. Data were analyzed by one-way ANOVA/Tukey's test $(\mathrm{p}<0.05)$. No statistically significant differences were found among DPSA, DPA, APSA, APA, and the control group. The aged PSA and PA achieved low bonding values and were statistically different from the control group, whereas the nonaged PSA and PA presented no statistically significant difference from the control group. Repairs with the proposed surface treatments were viable on both recent and aged restorations; however, phosphoric acid + adhesive alone were effective only on recent restorations.

Descriptors: Dental Materials; Composite Resins; Adhesives; Dental Restoration Repair.

\section{Introduction}

Adhesive dentistry offers the possibility of more conservative treatment for dental restorations, due to the reduction in the size of the cavity preparation and the bonding of restorative materials to the dental structure. It also allows for the repair of pre-existing restorations instead of their complete replacement, thereby preserving the healthy structure of the tooth, which is invariably placed at risk during the total removal of a restoration. ${ }^{1}$

However, there is a possibility that the repair may lead to an unacceptably weak restoration. Bonding between two layers of composite 
resin during a conventional restoration is generally ensured by the presence of a layer of non-reacted monomers. However, aged restorations do not have this layer of non-reacted monomers on the surface. ${ }^{2}$ This potential problem has been investigated in a number of studies focused on repairing composite resin, which have demonstrated that both the use of an intermediate bonding agent (adhesive and/or silane) and the roughening of the surface of the resin significantly improve the adhesion of the repair. ${ }^{1-5}$

Studies have investigated the bonding strength of repairs of aged composites through thermal cycling ${ }^{2,3,5,6}$ and immersion in hot water, acids, ${ }^{2,3}$ water, or artificial saliva ${ }^{1,4}$ for relatively short periods (24 $\mathrm{h}$ and 6 mos). ${ }^{1-5,7}$ However, studies are needed to determine the behavior of repairs bonded to aged restorations for a longer period of time and the behavior of this repair subjected to the same aging period.

The purpose of the present study was to assess the bond strength of repairs to composite resin subjected to different surface treatments and artificial accelerated aging.

\section{Methodology}

The materials used in the present study and their technical specifications are listed in Table 1. Two hundred cylindrical samples (CSs) were prepared and distributed into six groups subdivided into surface treatments as well as a control group with eight CSs.

The CSs from the six groups were prepared in two different portions. The first portion of the CS $(6 \times 2 \mathrm{~mm})$ was prepared with the aid of components 1,2 , and 3 of a Teflon matrix ${ }^{8}$ in a single layer and covered with a polyester strip and glass slide to flatten the surface of the resin. A one-Kg load was placed on the set for $10 \mathrm{~s}$. The glass slide was removed, and the resin was polymerized with the Demetron Optilux 401 device (Demetron/Kerr, Danbury, USA). Light intensity was measured by means of an analog radiometer (Gnatus, Ribeirão Preto, Brazil) and maintained between 580 and $600 \mathrm{~mW} /$ $\mathrm{cm}^{2}$. Following random distribution, half of the first portion of CSs $(n=96)$ were stored in distilled water in a biological incubator at $37 \pm 2{ }^{\circ} \mathrm{C}$ for $24 \mathrm{~h}$, and the other half $(\mathrm{n}=96)$ were subjected to C-UV accelerated aging for non-metallic specimens in an ASTM-G-53 machine (Adexim Comexim Matérias Primas Ltda., São Paulo, Brazil).

This accelerated aging system simulates environmental destructive capacity and predicts the relative durability of materials exposed to inclemency or a similar environment by simulating the chemical and physical environments that could partially replace the oral cavity conditions. ${ }^{9,10}$ Saliva is simulated by conditions of $100 \%$ humidity and a condensation process using distilled water saturated with oxygen. Light is simulated for eight sources of ultraviolet B (UV-B) light, with radiation concentrated between $280 \mathrm{~nm}$ and $320 \mathrm{~nm}$, facing the specimens at a distance of $50 \mathrm{~mm}$. The specimens were positioned on the machine's fixing plates for automatically repeated and alternating cycles of UV-B light and condensation. The program established for the cycles was $4 \mathrm{~h}$ of exposure to UV-B at $60^{\circ} \mathrm{C}$ and $4 \mathrm{~h}$ of condensation at $60^{\circ} \mathrm{C}$, with a maximum aging time of $192 \mathrm{~h}$.

The six groups with different surface treatments are listed in Table 2. Surface treatment procedures

Table 1 - Materials used in this study.

\begin{tabular}{c|c|c|c}
\hline Material & Composition & Lot & Manufacturer \\
\hline $\begin{array}{c}\text { Composite resin } \\
\text { Charisma - A2 }\end{array}$ & $\begin{array}{c}\text { Miller: highly dispersed silicon dioxide, 0.02 to } \\
0.07 \mu \mathrm{m}, \text { glass barium fluoridated aluminum } \\
(0.02 \text { to } 2 \mu \mathrm{m}), \text { medium size: } 0.7 \mu \mathrm{m}\end{array}$ & 010077 & $\begin{array}{c}\text { Heraeus Kulzer } \\
\text { GmbH \& Co. KG } \\
\text { Hanau, Germany }\end{array}$ \\
\hline $\begin{array}{c}\text { Silane coupling } \\
\text { agent }\end{array}$ & Silane, alcohol, acetic acid & 156139 & $\begin{array}{c}\text { Dentsply, Milford, } \\
\text { USA }\end{array}$ \\
\hline $\begin{array}{c}\text { Adhesive } \\
\text { Excite }\end{array}$ & $\begin{array}{c}\text { dimethacrylates, HEMA, acrylate of phosphinic } \\
\text { acid, highly dispersed silicon dioxide, initiators } \\
\text { and stabilizers in alcohol solution }\end{array}$ & G25619 & $\begin{array}{c}\text { Ivoclar Vivadent, } \\
\text { Schaan } \\
\text { Liechtenstein }\end{array}$ \\
\hline
\end{tabular}


Table 2 - Groups, repair time, and mechanical assay time.

\begin{tabular}{|c|c|c|}
\hline Groups & Surface Treatments & Repair and mechanical assay methodology \\
\hline G1 (PSA) & $37 \%$ phosphoric acid + silane + adhesive & \multirow{6}{*}{$\begin{array}{l}\text { A: Repair after } 24 \mathrm{~h} \text { and assay after } 24 \mathrm{~h} \\
\text { B: Repair after } 24 \mathrm{~h} \text { and assay after aging } \\
\text { C: Repair after aging and assay after } 24 \mathrm{~h} \\
\text { D: Repair after aging and assay after aging }\end{array}$} \\
\hline $\mathrm{G} 2(\mathrm{PA})$ & $37 \%$ phosphoric acid + adhesive & \\
\hline G3 (DPSA) & $\begin{array}{l}\text { Diamond bur }+37 \% \text { phosphoric acid } \\
+ \text { silane }+ \text { adhesive }\end{array}$ & \\
\hline G4 (DPA) & $\begin{aligned} \text { Diamond bur } & +37 \% \text { phosphoric acid } \\
& + \text { adhesive }\end{aligned}$ & \\
\hline G5 (APSA) & $\begin{array}{l}\text { Air abrasion with } \mathrm{Al}_{2} \mathrm{O}_{3}+37 \% \text { phosphoric } \\
\text { acid }+ \text { silane }+ \text { adhesive }\end{array}$ & \\
\hline G6 (APA) & $\begin{array}{l}\text { Air abrasion with } \mathrm{Al}_{2} \mathrm{O}_{3}+37 \% \text { phosphoric } \\
\text { acid }+ \text { adhesive }\end{array}$ & \\
\hline G7 & \multicolumn{2}{|c|}{ Control Group } \\
\hline
\end{tabular}

involved:

- 37\% phosphoric acid etching (FGM, Joinville, Brazil),

- silane and/or adhesive application,

- roughening with a diamond bur (4138; KG Sorensen, São Paulo, Brazil), and

- sandblasting (air abrasion) with $50 \mu \mathrm{m} \mathrm{Al}_{2} \mathrm{O}_{3}$ particles (Bio-Art, São Carlos, Brazil).

An orthodontic wire device was made to standardize the distance from the surface treatment $(5 \mathrm{~mm})$ and allow for perpendicular sandblasting for $10 \mathrm{~s}$ at 40 psi.

The repair of the composite resin was performed with the installation of component 4 on component 3 of the matrix. ${ }^{8}$ The insertion and polymerization of the repair followed the same procedures used for the first portion of the CS. The aging of the specimens was carried out in distilled water in a biological incubator at $37 \pm 2{ }^{\circ} \mathrm{C}$ for $24 \mathrm{~h}$. The control group with eight CSs received no aging or surface treatment. All 200 specimens were placed in a PVC ring (0.5 inches in diameter) with Jet colorless selfcuring acrylic resin (Clássico, São Paulo, Brazil). ${ }^{8}$ The mechanical trials were performed in the EMIC DL2000 universal testing machine (EMIC, São José dos Pinhais, Brazil) with a two-kN load and a $0.5 \mathrm{~mm} / \mathrm{min}$ crosshead speed. Bond strength in each group was estimated from the final shear strength data obtained based on ISO TR $11405^{11}$ and ISO $4049^{12}$ standards.

Debonded surfaces were examined by means of a binocular microscope to assess failure modes (QUIMIS, model Q724S-1, Diadema, Brazil) at 20× magnification. Failures were classified as adhesive (fracture on the adhesive interface of the resin portions), cohesive (fracture within one of the two resin portions), or mixed (simultaneous occurrence of adhesive and cohesive fractures). For a better microstructure analysis of the surface, three CSs subjected to the different surface treatments [37\% phosphoric acid; diamond bur (4138) + 37\% phosphoric acid; and air abrasion with $\mathrm{Al}_{2} \mathrm{O}_{3}(50 \mu \mathrm{m})+37 \%$ phosphoric acid] were prepared for analysis by scanning electron microscopy (SEM). The same procedures were performed for three CSs after aging. Specimens were prepared by the Ion Sputtering technique with a layer of gold about $100 \AA$ in thickness under vacuum of inert gas, and the SEM was operated at $15 \mathrm{kV}$.

Statistical analysis was performed with SPSS for Windows 15.0 (SPSS Inc., Chicago, USA) and involved one-way analysis of variance followed by pairwise comparison with Tukey's test $(\mathrm{p}<0.05)$ to determine differences between and among shear strengths of groups.

\section{Results}

Analysis of variance revealed an influence of both surface treatment and accelerated aging before and after composite repair. Statistically significant differences $(\mathrm{p}<0.001)$ were found between some treatment groups (Table 3). Groups 3, 4, 5, and 6 under conditions A, B, C and D showed no statisti- 
cally significant differences from the control group, with the exception of groups $4 \mathrm{~A}$ and $5 \mathrm{D}$. Groups $1 \mathrm{C}, 1 \mathrm{D}, 2 \mathrm{C}$, and $2 \mathrm{D}$ had significantly lower bond strength values in comparison with the other groups and with the control group. Groups 1B, 2A, 4A, and $5 \mathrm{D}$ had higher bond strength values in comparison with Groups 1C, 1D, 2C, and 2D (Table 3).

Fracture analysis revealed that several groups presented either cohesive $(\mathrm{N}=149)$ or mixed

Table 3 - Mean and standard deviation values for shear bond strength data (in $\mathrm{MPa}$ )

\begin{tabular}{|c|c|c|c|c|}
\hline Groups & A & B & C & $\mathrm{D}$ \\
\hline G1 & $\begin{array}{r}20.6^{\circ} \\
(2.3)\end{array}$ & $\begin{array}{l}15.7^{\mathrm{bcd}} \\
(1.4)\end{array}$ & $\begin{array}{r}5.8^{e} \\
(2.2)\end{array}$ & $0^{f}$ \\
\hline G2 & $\begin{array}{r}14.5^{\mathrm{d}} \\
(1.7)\end{array}$ & $\begin{array}{l}18.8^{\mathrm{abc}} \\
(2.4)\end{array}$ & $\begin{array}{r}6.7 \mathrm{e} \\
(0.4)\end{array}$ & $\begin{array}{r}5.8^{\mathrm{e}} \\
(1.7)\end{array}$ \\
\hline G3 & $\begin{array}{l}16.5^{\mathrm{abcd}} \\
(3.6)\end{array}$ & $\begin{array}{l}19.5^{\mathrm{abc}} \\
(3.2)\end{array}$ & $\begin{array}{l}16.7^{\mathrm{abcd}} \\
(1.0)\end{array}$ & $\begin{array}{l}17.5^{\mathrm{abcd}} \\
(2.2)\end{array}$ \\
\hline G4 & $\begin{array}{l}15.5^{\mathrm{cd}} \\
(3.6)\end{array}$ & $\begin{array}{l}17.7^{\mathrm{abcd}} \\
(1.1)\end{array}$ & $\begin{array}{c}19.8^{\mathrm{ab}} \\
(2.3)\end{array}$ & $\begin{array}{l}18.6^{\text {abcd }} \\
(2.5)\end{array}$ \\
\hline G5 & $\begin{array}{l}16.3^{\mathrm{abcd}} \\
(3.6)\end{array}$ & $\begin{array}{l}18.8^{a b c} \\
(3.2)\end{array}$ & $\begin{array}{l}17.1^{\mathrm{abcd}} \\
(1.0)\end{array}$ & $\begin{array}{l}15.7^{\mathrm{bcd}} \\
(2.2)\end{array}$ \\
\hline G6 & $\begin{array}{l}17.3^{\mathrm{abcd}} \\
(3.6)\end{array}$ & $\begin{array}{l}17.5^{\mathrm{abcd}} \\
(1.1)\end{array}$ & $\begin{array}{l}18.6^{\mathrm{abcd}} \\
(2.3)\end{array}$ & $\begin{array}{l}17.1^{\mathrm{abcd}} \\
(2.5)\end{array}$ \\
\hline G7 & \multicolumn{4}{|c|}{$\begin{array}{l}20.3^{a} \\
(1.6)\end{array}$} \\
\hline
\end{tabular}

Different lowercase letters indicate statistically significant different mean values between groups $(p<0.05)$. One-way ANOVA + Tukey's test.
$(\mathrm{N}=16)$ failures. Adhesive failure occurred predominantly in groups that received only phosphoric acid as surface treatment and repair after aging (G1C, G1D, G2C, and GD2) (Graph 1).

SEM analyses of resin composite surfaces treated with phosphoric acid revealed a large number of filler particles, but after aging only a few particles remained at the surface (Figure 1, A and B). Surfaces roughened with a diamond bur or sandblasted with $\mathrm{Al}_{2} \mathrm{O}_{3}$ presented a similar pattern, with an irregular surface topography (Figure 1, C-F).

\section{Discussion}

Clinical studies assessing the long-term behavior of composite resins are extremely difficult. It is virtually impossible to standardize the oral status of each patient, which hinders the prediction of durability and the comparison of dental materials. ${ }^{13}$ Thus, laboratory aging methods have been proposed to standardize the research and facilitate comparisons among studies carried out by different authors. ${ }^{14}$ Moreover, artificial aging methods allow for assessment of the degradation of materials in a short period that would otherwise take months or even years of use in the oral cavity. ${ }^{14,15}$

Thermal cycling, ${ }^{2,3,5,6,14}$ storage of the dry material at $37{ }^{\circ} \mathrm{C}$ in acids, and immersion in water, artificial saliva, or hot water ${ }^{1-4,7,16}$ are some of the

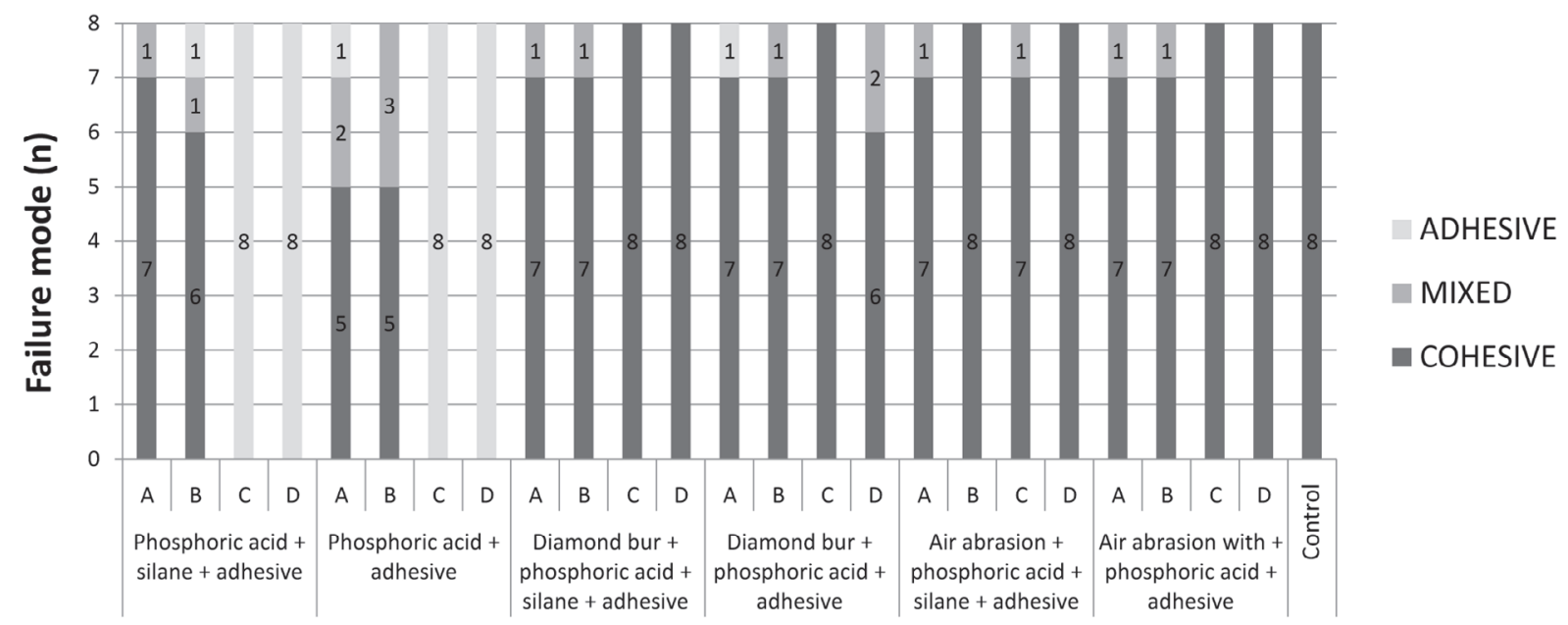

Surface treatment groups and repair and mechanical assay methodology

Graph 1 - Failure mode distribution according to surface treatment and repair and mechanical assay methodology. 

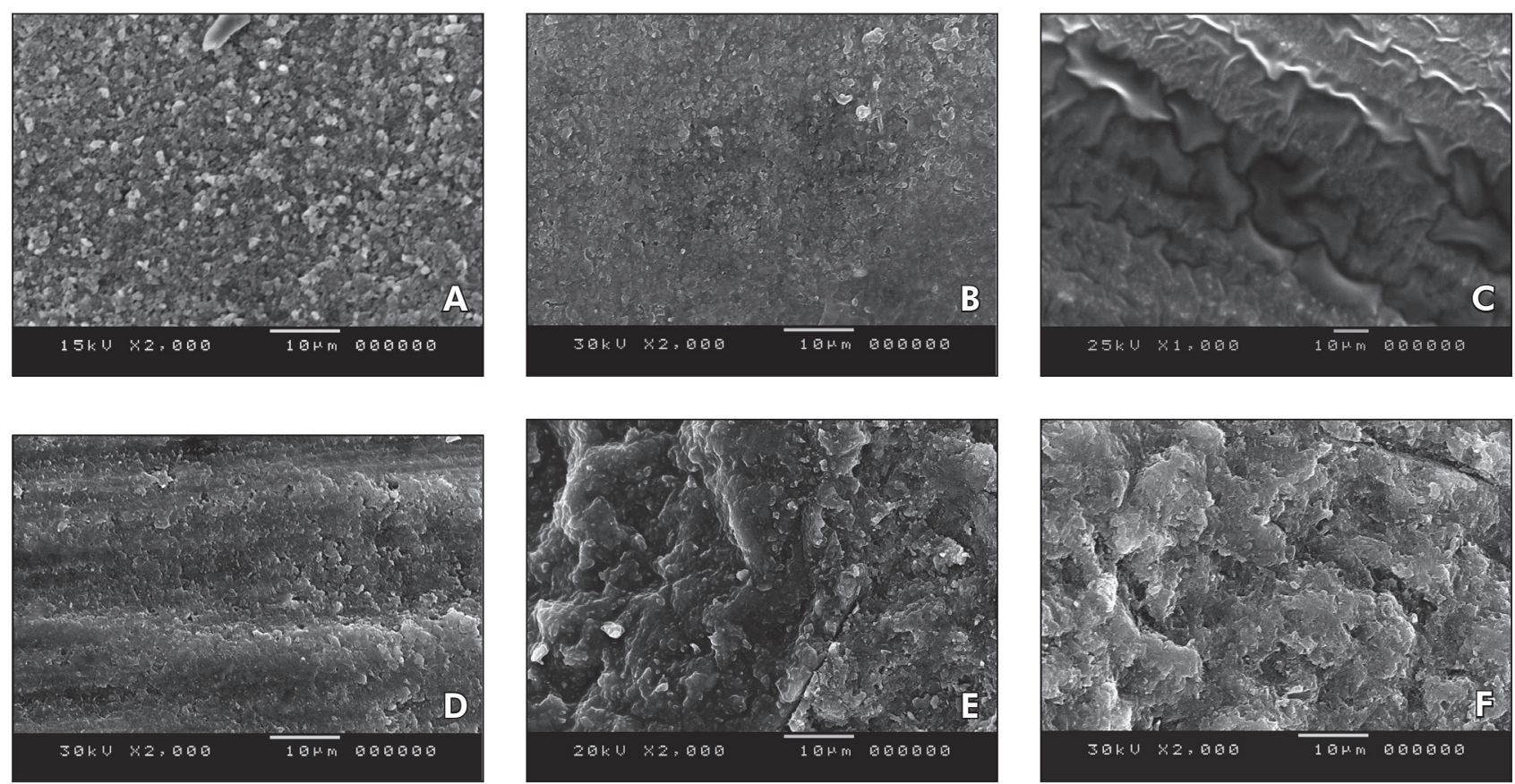

Figure 1 - Scanning electron microscopy of resin surfaces submitted to different treatments: (A) Phosphoric Acid; (B) Aged Phosphoric Acid; (C) Diamond Bur; (D) Aged Diamond Bur; (E) Air Abrasion; (F) Aged Air Abrasion.

methods used to artificially age composite resins and other dental materials. As in the present study, Accelerated Artificial Aging (AAA) for non-metallic specimens has been considered an advantageous system to age materials. Under the action of repeated cycles of UV-B light exposure and distilled water condensation, artificial aging simulates the chemical and physical oral environments, producing, in a relatively short period, degradation similar to that which a composite resin would undergo in its clinical life. ${ }^{9,10,15,17}$

The resins that were repaired in $24 \mathrm{~h}$ (except Groups 1B, 2A, and 4A) achieved high bond strength values, with no statistically significant differences in comparison with the control group. This likely occurred because the final curing of the composite resin occurred approximately $72 \mathrm{~h}$ following the restoration, and, during this period, non-reacted monomers are still found in the resin. ${ }^{16}$ These monomers are fundamental during the incremental execution of the composite resin restoration, since they allow for co-polymerization with the monomers of the new layer of composite resin, thereby maintaining the cohesive strength of the material. ${ }^{18}$ Moreover, there was an increase in roughness of the resin surface prior to the repair in Groups 3, 4, 5, and 6, which may have contributed to the bond strength. ${ }^{19}$

The groups treated only with $37 \%$ phosphoric acid were effective only when repaired in $24 \mathrm{~h}$, regardless of the time of the mechanical assay. Groups $1 \mathrm{C}, 1 \mathrm{D}, 2 \mathrm{C}$, and $2 \mathrm{D}$, which were aged prior to the repair, had very low bond strength values. This is likely due to the lack of non-reacted monomers on the surface and the inability of phosphoric acid to create micro-retention sites on the surface of the resin $^{3}$ (Figure 1, B).

The groups subjected to surface treatment with DPAS, DPA, APAS, or APA had high bond strength values, with no statistically significant differences from the control group, regardless of when the repair or mechanical assay was performed (except Groups 4A and 5D). The high values may be the consequence of micro-retention sites caused by the diamond bur and $\mathrm{Al}_{2} \mathrm{O}_{3}$ on the surface of the composite resin ${ }^{3,19}$ (Figure 1, C-F).

The most commonly used surface modifiers in numerous applications in dental technology are silane coupling agents (silanes). These agents have the characteristic property of bonding dissimilar inorganic and organic materials together. Silanes form 
a large chemical group of hybrid inorganic-organic compounds containing direct $\equiv \mathrm{Si}-\mathrm{C} \equiv$ bonds. In the dental sciences, silanes are used in resin-based composites for filler surface modification, as a coupling agent for composite-to-composite surfaces, and to condition partially fixed ceramic and silica-coated prosthetic metals. The most familiar silane, 3-methacryloyloxypropyltrimethoxysilane, has been evaluated with filler particles of composite resins and in glass fiber lamination..$^{20,21}$

However, groups in which silane were used achieved results similar to those of groups in which silane was not used. Similar results have been reported in other studies. ${ }^{21}$ The surface treatment methods may not have adequately exposed the charged particles, and the scarcity of non-reacted monomers may have made the silane obsolete in the methodology proposed in the present study.

Regarding the failure mode, most were cohesive, except in Groups 1C, 1D, 2C, and 2D, in which the failure was adhesive. Della Bona and colleagues discussed this problem and concluded that shear tests measure the cohesive strength of the underlying composite rather than the adhesive strength of the bond. ${ }^{22}$ However, the underlying composite will fracture only if the adhesive bond to the overlying composite is strong. ${ }^{4}$

Clinically, composite resin repairs occur after a certain time following the preparation of the composite resin. With this in mind, when assessing the

\section{References}

1. Rodrigues SA Jr, Ferracane JL, Della Bona A. Influence of surface treatments on the bond strength of repaired resin composite restorative materials. Dent Mater. 2009 Apr;25(4):44251.

2. Brendeke J, Ozcan M. Effect of physicochemical aging conditions on the composite-composite repair bond strength. J Adhes Dent. 2007 Aug;9(4):399-406.

3. Ozcan M, Barbosa SH, Melo RM, Galhano GA, Bottino MA. Effect of surface conditioning methods on the microtensile bond strength of resin composite to composite after aging conditions. Dent Mater. 2007 Oct;23(10):1276-82.

4. Padipatvuthikul P, Mair LH. Bonding of composite to water aged composite with surface treatments. Dent Mater. 2007 Apr;23(4):519-25. groups under conditions $\mathrm{C}$ and $\mathrm{D}$, we noted that the surface treatments with DPAS, DPA, APAS, and APA achieved a satisfactory performance in relation to the control group, unlike the groups that used PAS or PA as the surface treatment, which achieved very low values.

No single laboratory assay is capable of reproducing all the conditions a particular material undergoes in the oral cavity, which is one of the limitations of in vitro studies.

In addition, the methodological differences in each study may contribute to a variety of results, making the observation of these differences extremely important. It would therefore be interesting for further studies to compare various types of assays using the same methodology.

\section{Conclusions}

Resin repairs after surface treatments with DPAS, DPA, APAS, or APA had bond values similar to those of the control group, being viable in both recent and aged restorations. Surface treatment with $37 \%$ phosphoric acid + adhesive should not be used alone in composite resin repairs.

\section{Acknowledgements}

The authors acknowledge the Centro de Desenvolvimento da Tecnologia Nuclear (CDTN) - Federal University of Minas Gerais, for support in the scanning electronic microscopy

5. Papacchini F, Toledano M, Monticelli F, Osorio R, Radovic I, Polimeni A, et al. Hydrolytic stability of composite repair bond. Eur J Oral Sci. 2007 Oct;115(5):417-24.

6. Voltarelli FR, dos Santos-Daroz CB, Alves MC, Peris AR, Marchi GM. Effect of different light-curing devices and aging procedures on composite Knoop microhardness. Braz Oral Res. 2009 Oct-Dec;23(4):473-9.

7. Cassoni A, Ferla Jde O, Albino LG, Youssef MN, Shibli JA, Rodrigues JA. Argon ion laser and halogen lamp activation of a dark and light resin composite: microhardness after longterm storage. Lasers Med Sci. 2010 Nov;25(6):829-34.

8. Ribeiro JC, Gomes PN, Moysés MR, Dias SC, Pereira LJ, Ribeiro JG. Shear strength evaluation of composite-composite resin associations. J Dent. 2008 May;36(5):326-30. 
9. Gomes PN, Dias SC, Moyses MR, Pereira LJ, Negrillo BG, Ribeiro JC. Effect of artificial accelerated aging on Vickers microhardness of composite resins. Gen Dent. 2008 NovDec;56(7):695-9.

10. Rattacaso RM, da Fonseca Roberti Garcia L, Aguilar FG, Consani S, de Carvalho Panzeri Pires-de-Souza F. Bleaching agent action on color stability, surface roughness and microhardness of composites submitted to accelerated artificial aging. Eur J Dent. 2011 Apr;5(2):143-9.

11. International Organization for Standardizaton. ISO/TS 11405:2003 Dental materials - Testing of adhesion to tooth structure. Switzerland. Genève: International Organization for Standardization. 2003. 15 p.

12. International Organization for Standardizaton. ISO 4049:2000 Dentistry - Polymer-based filling, restorative and luting materials. $3^{\text {rd }}$ ed. Genève: International Organization for Standardization. 2000. 27 p.

13. Mjör IA, Gordan VV. Failure, repair, refurbishing and longevity of restorations. Oper Dent. 2002 Sep-Oct;27(5):528-34.

14. Loomans BA, Vivan Cardoso M, Roeters FJ, Opdam NJ, De Munck J, Huysmans MC, et al. Is there one optimal repair technique for all composites? Dent Mater. 2011 Jul;27(7):701-9.

15. Goiato MC, Santos DM, Haddad MF, Pesqueira AA. Effect of accelerated aging on the microhardness and color stability of flexible resins for dentures. Braz Oral Res. 2010 JanMar;24(1):114-9.
16. Mair L, Padipatvuthikul P. Variables related to materials and preparing for bond strength testing irrespective of the test protocol. Dent Mater. 2010 Feb;26(2):e17-23.

17. Zanin FR, Garcia Lda F, Casemiro LA, Pires-de-Souza Fde C. Effect of artificial accelerated aging on color stability and surface roughness of indirect composites. Eur J Prosthodont Restor Dent. 2008 Mar;16(1):10-4.

18. Cavalcanti AN, De Lima AF, Peris AR, Mitsui FH, Marchi GM. Effect of surface treatments and bonding agents on the bond strength of repaired composites. J Esthet Restor Dent. 2007;19(2):90-8.

19. Vivas J, Yaman P, Taylor G. Effect of different surface treatments on the shear and flexural re-bond strengths of a micro-hybrid composite. J Contemp Dent Pract. 2009 Sep 1;10(5):E001-8.

20. Matinlinna JP, Vallittu PK. Silane based concepts on bonding resin composite to metals. J Contemp Dent Pract. 2007 Feb $1 ; 8(2): 1-8$.

21. Matinlinna JP, Lassila LV, Ozcan M, Yli-Urpo A, Vallittu PK. An introduction to silanes and their clinical applications in dentistry. Int J Prosthodont. 2004 Mar-Apr;17(2):155-64.

22. Della Bona A, Anusavice KJ, Mecholsky JJ Jr. Failure analysis of resin composite bonded to ceramic. Dent Mater. 2003 Dec;19(8):693-9. 